\title{
Economics Model Analysis of Defence Expenditure and Economic Growth in the US Xiao-lei ZHENG ${ }^{1}$, Ji REN ${ }^{2,{ }^{*}}$ and Zhi-jun FENG ${ }^{2}$ \\ ${ }^{1}$ The Logistics College, Beijing, China \\ ${ }^{2}$ The Logistics Science Institute, Beijing, China \\ *renji201203@163.com
}

\begin{abstract}
Keywords: Defence expenditure, Economic growth, ADF test, Cointegration analysis, Grainger causality test.
\end{abstract}

\begin{abstract}
This paper expounds on the relationship between defence expenditure and economic growth. By selecting defence expenditure and economic indicators including GDP, gross value of imports and exports, fuel import and export value and foreign direct investment in the US from 1991 to 2010 as sample spaces, the paper is modeled on some analytical methods as ADF test, cointegration analysis and Grainger causality test. The paper analyzes the long-term equilibrium relationship between defence expenditure and economic growth, concluding that economic growth is the Granger cause of defence expenditure growth. Meanwhile, defence expenditure growth will have a positive impact on economic growth.

The relationship between defence expenditure and economic growth is one hot topic in modern economics and military economics. Chinese and foreign scholars have conducted discussion and modeling analysis on this issue from different perspectives. Zhoulai Lu [1] summarizes various research results between "defence expenditure" and "economic growth" both at home and abroad, and the typical models are "Keynesian model", "Feder-Ram model" and "public products model". Chen [2], Xiaopeng Tang [3], Zhongyan Wang [4] and Zhengqian Xu [5], etc. conduct modeling analysis on the relationship between China's defence expenditure and economic growth with the methods of Grainger test and cointegration test, etc. Based on the samples of defense expenditure and important economic indicators in the US from 1991 to 2010, the thesis carries out a detailed modeling analysis and deliberates on this hot issue combined with the modeling results of the above thesis.
\end{abstract}

\section{Empirical Research}

\section{Data Selection}

The paper selects the US military expenditure (ME) as a measure of military power, chooses the US GDP as a measure of economic development, and selects total foreign trade volume (EX), fuel import and export value (OR) and foreign direct investment (CA) as the indicators measuring the degree of export-oriented economy. In order to eliminate the differences between different indicators caused by different measurement units, the writer of the paper unifies measurement units of all indicators as "one hundred million dollars". The United States' military and economic statistics from 1991 to 2010 is shown in Table 1[6,7]: 
Table 1: Relevant economic indicators in the US from 1991 to 2010

\begin{tabular}{|c|c|c|c|c|c|}
\hline Year & $\begin{array}{c}\text { Military } \\
\text { expenditure } \\
(\mathrm{ME})\end{array}$ & $\begin{array}{l}\text { Foreign trade } \\
\qquad(\mathrm{EX}) \\
\text { (one hundred } \\
\text { million dollars) }\end{array}$ & $\begin{array}{c}\text { Fuel import } \\
\text { and export } \\
(\mathrm{OR}) \\
\text { (one hundred } \\
\text { million } \\
\text { dollars) }\end{array}$ & $\begin{array}{l}\text { Foreign direct } \\
\text { investment } \\
\text { (CA) } \\
\text { (one hundred } \\
\text { million dollars) }\end{array}$ & $\begin{array}{c}\text { GDP } \\
\text { (one } \\
\text { hundred } \\
\text { million } \\
\text { dollars) }\end{array}$ \\
\hline 1991 & 2803 & 9301 & 677.316 & 314 & 55541 \\
\hline 1992 & 3051 & 10021 & 703.657 & 426.6 & 57109 \\
\hline 1993 & 2976 & 10682 & 649.964 & 779.5 & 60277 \\
\hline 1994 & 2881 & 12018 & 691.872 & 752.1 & 63370 \\
\hline 1995 & 2789 & 13556 & 743.231 & 920.7 & 70384 \\
\hline 1996 & 2714 & 15471 & 897.7 & 919 & 74187 \\
\hline 1997 & 2763 & 15877 & 957.933 & 1218.4 & 78440 \\
\hline 1998 & 2743 & 16265 & 1035.187 & 1461 & 87202 \\
\hline 1999 & 2810 & 17522 & 1143.808 & 1425.5 & 92069 \\
\hline 2000 & 3017 & 20412 & 1546.384 & 1426.26 & 98988 \\
\hline 2001 & 3027 & 19083 & 1422.489 & 1139.8 & 100653 \\
\hline 2002 & 4320 & 18963 & 1339.254 & 1197.4 & 104290 \\
\hline 2003 & 4920 & 20279 & 1781.083 & 1518.8 & 109486 \\
\hline 2004 & 5360 & 23454 & 2355.858 & 2224 & 116573 \\
\hline 2005 & 5620 & 26338 & 3241.563 & 1530.69 & 125643 \\
\hline 2006 & 5710 & 29547 & 3836.122 & 2216.64 & 131639 \\
\hline 2007 & 5860 & 31686 & 4186.918 & 3137.87 & 138112 \\
\hline 2008 & 6290 & 34569 & 4440.325 & 3304.91 & 142969 \\
\hline 2009 & 6800 & 26613 & 3421.755 & 2480.74 & 138636 \\
\hline 2010 & 6983 & 32474 & 4550.613 & 3289.05 & 144471 \\
\hline
\end{tabular}

Due to the significant differences in the order of magnitude of various statistical indicators, there may be heteroscedasticity and violent fluctuation. In an attempt to eliminate the possibility of the existence of violent fluctuation, we deal with the natural logarithm processing of the above five indicators sequences. Then, after the selection of the logarithm, the sequence is expressed as LME, LEX, LOR, LCA and LGDP. The analysis of the relationship of these indicators in this paper is the quantitative analysis of the logarithmic sequence. The data of the selection of the logarithm of the above five indicators sequences is shown in Table 2. 
Table 2: Natural logarith m of relevant economic indicators in the US from 1991 to 2010

\begin{tabular}{|c|c|c|c|c|c|}
\hline Year & LME & LEX & LOR & LCA & LGDP \\
\hline 1991 & 7.938446 & 9.1378772 & 6.518137929 & 5.749392986 & 10.92488 \\
\hline 1992 & 8.023225 & 9.21243817 & 6.556291022 & 6.055846806 & 10.95272 \\
\hline 1993 & 7.998335 & 9.276315361 & 6.476916977 & 6.658652688 & 11.00671 \\
\hline 1994 & 7.965893 & 9.394160805 & 6.539400967 & 6.622869294 & 11.05675 \\
\hline 1995 & 7.933438 & 9.514584533 & 6.611006898 & 6.82513425 & 11.16172 \\
\hline 1996 & 7.906179 & 9.646722583 & 6.799835937 & 6.823286122 & 11.21434 \\
\hline 1997 & 7.924072 & 9.6726268 & 6.864777838 & 7.105293802 & 11.27009 \\
\hline 1998 & 7.916807 & 9.696770839 & 6.942337366 & 7.286876412 & 11.37598 \\
\hline 1999 & 7.94094 & 9.771212513 & 7.042118326 & 7.262277908 & 11.43029 \\
\hline 2000 & 8.012018 & 9.923878242 & 7.343674581 & 7.262810913 & 11.50275 \\
\hline 2001 & 8.015327 & 9.856553165 & 7.260163433 & 7.038608087 & 11.51943 \\
\hline 2002 & 8.371011 & 9.850244991 & 7.199868022 & 7.087907818 & 11.55493 \\
\hline 2003 & 8.501064 & 9.917341147 & 7.484976885 & 7.325675828 & 11.60355 \\
\hline 2004 & 8.586719 & 10.06279634 & 7.764660271 & 7.707062655 & 11.66627 \\
\hline 2005 & 8.634087 & 10.17876804 & 8.0838109 & 7.333473893 & 11.7412 \\
\hline 2006 & 8.649974 & 10.29373749 & 8.252217239 & 7.703747815 & 11.78782 \\
\hline 2007 & 8.675905 & 10.36363022 & 8.339720181 & 8.051299505 & 11.83582 \\
\hline 2008 & 8.746716 & 10.45071261 & 8.398482851 & 8.10316452 & 11.87038 \\
\hline 2009 & 8.824678 & 10.1891551 & 8.137908856 & 7.816312182 & 11.83961 \\
\hline 2010 & 8.851234 & 10.38819505 & 8.423017228 & 8.098354048 & 11.88083 \\
\hline
\end{tabular}

\section{Sequence Stationarity Test}

ADF test of the above five natural logarithm series is carried out with the help of EViews7. From the test results, the five sequences are all non-stationary and first order difference sequence is stationary. They were all integrated of order one I (I) and can carry on cointe gration analysis.

\section{Cointegration Analysis of Defence Expenditure and Economic Indicator}

Adopting cointegration test on the basis of model regression residuals, the paper carries out cointegration test on natural logarithm sequence of defence expenditure and various major economic indicators in the US from 1991 to 2010. As a comprehensive indicators influenced by many factors, we can draw a conclusion that there will not be a very strict cointegration relationship between defence expenditure and economic indicators. Therefore, this paper chooses $10 \%$ instead of more strict $5 \%$ and $1 \%$ as the inspection of critical value, and test results is shown in Table 3: 
Table 3: Analytical results of defence expenditure and economic indicators

\begin{tabular}{ccccc}
\hline Sequence & Regression model & Tstatistic & $\begin{array}{c}10 \% \\
\text { criticality }\end{array}$ & Conclusion \\
\hline LME, LGDP & LME=-2.93+0.98LGDP & -2.13 & -1.60 & $\begin{array}{c}(1,0) \\
\text { Cointegration }\end{array}$ \\
\hline LME, LEX & LME=-0.66+0.77LEX & -1.59 & -1.60 & $\begin{array}{c}\text { Non } \\
\text { Cointegration }\end{array}$ \\
\hline LME, LOR & LME=4.74+0.48LOR & -2.01 & -1.60 & $\begin{array}{c}(1,0) \\
\text { Cointegration }\end{array}$ \\
\hline LME, LCA & LME=5.06+0.45LCA & -1.68 & -1.60 & $\begin{array}{c}(1,0) \\
\text { Cointegration }\end{array}$ \\
\hline
\end{tabular}

It is thus obvious that there is a long-run equilibrium relationship between defence expenditure and the economic indicators such as GDP, fuel import and export and foreign direct investment. Although there is no cointegration relationship between defence expenditure and total foreign trade volume in the model, the absolute value of T statistic is only 0.1 less than the critical value.

\section{Grange r Causality Test of Defence Expenditure and Economic Indicators}

\section{Grange r Causality Test of LME and LGDP}

Granger causality test results of the above two sequences with lagged value 2 by EViews7 is shown in Table 4.

Table 4: Granger causality test result of LME and LGDP

\begin{tabular}{cccc}
\hline Null Hypothes is & Obs & F-Statistic & Prob \\
\hline LGDP does not Granger Cause LME & 18 & 5.95823 & 0.0146 \\
\hline LMEdoes not Granger Cause LGDP & & 0.00147 & 0.9985 \\
\hline
\end{tabular}

As shown above, we reject the first hypothesis "LGDP does not Granger cause LME" (i.e., LGDP is not the cause of the change of LME and the absolute value of F statistic is greater than the $1 \%$ critical value) because LGDP is the cause of the change of LME. But we should not reject the second hypothesis "LME does not Granger Cause LGDP" (i.e., LME is not the cause of the change of LGDP and the absolute value of $F$ statistic is less than the $10 \%$ critical value).

Therefore, the law presented in the data in the US from1991 to 2010 is below: the change of GDP is the Granger cause of defence expenditure and the delay is two years.

\section{Grange r Causality Test of LME and LOR}

Granger causality test results of the above two sequences with lagged value 1 by EViews7 is shown in Table 5.

Table 5: Granger causality test result of LME and LOR

\begin{tabular}{cccc}
\hline Null Hypothes is & Obs & F-Statistic & Prob \\
\hline LOR does not Granger Cause LME & 19 & 1.74031 & 0.2057 \\
\hline LME does not Granger Cause LOR & & 2.77445 & 0.1152 \\
\hline
\end{tabular}

As shown above, we don't reject the first hypothesis "LOR does not Granger cause LME" (i.e., LOR is not the cause of the change of LME and the absolute value of F statistic is less than the $5 \%$ critical value). But we reject the second hypothes is "LME does not Granger Cause LOR" (i.e., LME is not the cause of the change of LOR and the absolute value of F statistic is greater than the $1 \%$ critical value) because LME is the cause of the change of LOR. 
Therefore, the law presented in the data in the US from1991 to 2010 is below: the change of defence expenditure is the Granger cause of the change of fuel import and export, and the delay is one year.

\section{Grange r Causality Test of LME and LCA}

Granger causality test results of the above two sequences by EViews7 is shown in Table 6.

Table 6: Granger causality test of LME and LCA

\begin{tabular}{cccc}
\hline Null Hypothesis & Obs & F-Statistic & Prob \\
\hline LCA does not Granger Cause LME & 19 & 0.13646 & 0.7167 \\
\hline LME does not Granger Cause LCA & & 5.55235 & 0.0315 \\
\hline
\end{tabular}

As shown above, we don't reject the first hypothesis "LCA does not Granger cause LME" (i.e., LCA is not the cause of the change of LME and the absolute value of F statistic is less than the $10 \%$ critical value). But we reject the second hypothesis "LME does not Granger Cause LCA" (i.e., LME is not the cause of the change of LCA and the absolute value of F statistic is greater than the $1 \%$ critical value) because LME is the cause of the change of LCA.

Therefore, the law presented in the data in the US from1991 to 2010 is below: the change of defence expenditure is the Granger cause of foreign direct investment and the delay is one year.

\section{Conclusion}

The paper conducts stationarity test, cointegration test and Granger causality analysis on military indicators and various economic indicators in the US from 1991 to 2010. It selects the indicator "military expenditure" representing military strength and four indicators representing economy: GDP, foreign trade, fuel import and export and foreign direct investment. The statistical analysis of the five data after selecting natural logarithm proves the relationships between them.

The original sequence of these five time series is non-stationary, but first order difference of them is stationary. It shows that they are not self-related sequences and the change is not simply influenced by time, but also influenced by other factors. So this conclusion is the basis of follow-up analysis.

We have analyzed the cointegration relationship between defence expenditure and four economic indicators. The analysis result proves that defence expenditure has cointegration relationship with all the four economic indicators. Though some cointegration relationship can show up only at levels of $5 \%$ or even $10 \%$, which is not rigid cointegration relationship, this also shows the complexity of the relationship between military force and economic development. They are all affected by a great many factors and complete description of its change rules can not be fully delineated by these indicators. But our analysis demonstrates the overall relationship between military and various economic indicators.

By Granger causality analysis, we also find that GDP is the Granger cause of defence expenditure in the US from 1991 to 2010, and the effect of which is reflecting in the first year and second year after the change of GDP, mainly in the second year. In other words, defence expenditure will make constructive adjustments in the following one or two years when the main GDP indicators measuring American economy change. Clearly, the conclusion not only reflects the direct impact of the economy on military forces, but also shows that the US adopts the strategic initiatives 
of revising defence expenditure vigorously to make it coordinate with economic development.

In addition, when doing Granger causality analysis, we find the change of defence expenditure is Ganger cause of fuel export and import and foreign direct investment in the US from 1991 to 2010. Namely, the last two sequences are the indicators chosen by as to measure the degree of economic openness. American's adjustment of defence expenditure will have positive effect on economic growth. While it should be point out that with regard to Granger causality test result, this kind of causality is not very distinct and economic growth is also affected by other factors.

To sum up, quantitative analysis of military force and economic indicators in the US from 1991 to 2010 embodies the following laws: after the change of GDP, the US will adjust defence expenditure actively in the following one or two years in order to make it coordinate with economy. In the mean time, the change of defence expenditure will have a certain impact on economic growth of the United States, which reflects dialectical relationship between military force and economic growth.

\section{References}

[1] Zhoulai Lu. Economic Perspectives, 2010(10) :132-137.

[2] Chen, C.H. Journal of Economic Studies, 2011(3):37-43.

[3] Xiaopeng Tang. Military Economic Research, 2011(9):9-11.

[4] Zhongyan Wang. Journal of Air Force Radar Academy, 2009(6):200-202.

[5] Zhengqian Xu. Military Economic Research, 2012(5):13-16.

[6] National Bureau of Statistics. International Statistical Yearbook. Beijing: China Statistics press, $2013: 66-78$.

[7] Ian Anthony. SIPRI Yearbook. Beijing: Current Affairs Press, 2013:82-86. 